\title{
The development of an operational second dimensional value system
}

Received (in revised form): 8th July, 2002

\section{Flemming Hansen}

is a professor at the Copenhagen Business School, and head of Forum for Advertising Research. From 1973 to 1989 he was part-owner and chairman of the board for AIM Research in Denmark. He was vice president for ESOMAR and EMAC. He is advisor to the Danish Circulation Board (Oplagskontrollen), the Ministry of Communication and a committee set up by the Danish Prime Minister. He is member of the board for Gallup AS - a part of Taylor Nilson/Sofres. He has written more than 100 articles in international journals and proceedings and is author of several books on consumer behaviour and communication.

\section{Rolf Randrup}

is responsible for the development and administration of the Danish Media Index with 24,000 interviews annually. A Bachelor in Economics from the Aarhus School of Business, he has been involved in market research at Gallup Denmark for more than 40 years. He has written a number of articles and contributed to articles and textbooks. He has given presentations at ESOMAR, the Advertising Research Foundation and Worldwide Readership Research Symposium.

\section{Regin Reinert}

is responsible for the technical development of Gallup Kompas. He is a Master of Science in statistics, University of Copenhagen and has published articles about Danish voters in the EU context.

Flemming Hansen

Forum for Advertising

Research,

Copenhagen Business

School, Solbjerg Plads 3, DK-2000 Frederiksberg,

Denmark.

Tel: +45 38152100 ; Fax: +4538152101 ; e-mail: fh.marktg@cbs.dk

\begin{abstract}
Sociologists, linguists and market researchers have studied values and lifestyles for decades. In the present paper, the authors look at the motivation behind their approaches and suggest the presence of a general communality for the solutions, which, in turn, made it possible to discern basic evaluation dimensions common for all of these. They further suggest a general two-dimensional solution and demonstrate how it compares with other systems and how it functions.
\end{abstract}

\section{INTRODUCTION}

Since its introduction in 1994, Kompas has been a very successful value measurement system used for media planning, marketing strategy formulation and many other purposes. It has been used particularly in the Nordic countries, Poland and Israel, and is coming into use in other countries too. The Kompas system is unique in the sense that it is based upon people's everyday opinions and interpreted in terms of underlying values. Furthermore, it is easy to use because it works with an easily interpretable two-dimensional solution traditional $v$ s. modern opinions, and social $v s$. individual values.
Basically, the Kompas system divides the world (described along the two previously mentioned dimensions) into nine segments, as shown in Figure 1. Gallup used Kompas for the viewers of the television programme 'Wheel of Fortune' (1A) (gross rating points (GRP) in segments) and the film 'Hoffa' (1B). The much more traditional profile describing 'Wheel of Fortune' viewers as compared with the viewers of the more serious movie is obvious. Looking at the total population, the nine segments are practically equal in size. The difference between the viewers of the two programmes is obvious. 'Hoffa' appeals to a more modern and individually oriented 


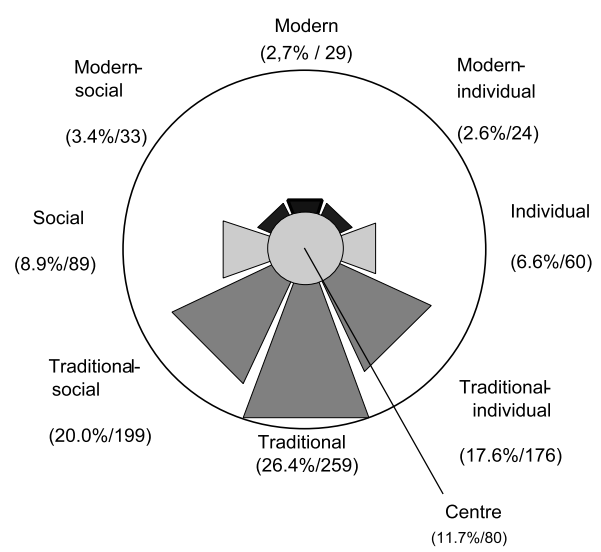

Gallup Kompas

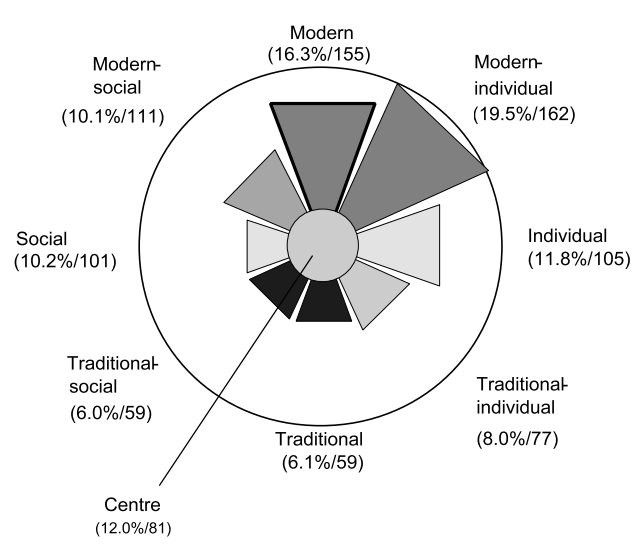

Key

Figure 1 Kompas diagrams for viewers of 'Wheel of Fortune' (A) and 'Hoffa' (B) Traditional as the Z-value $=10,4068$ exceeds the limit of $+/-1.96$

audience than 'Wheel of Fortune', which appeals to much more traditionally oriented viewers. Similar differences appear between users of different products (ie personal computer $v$ s. family magazine readers), between different brands (ie Absolut Vodka vs. Smirnoff Vodka) or between opinions of voters of different political parties.

In Figure $1 \mathrm{~A}$ and $\mathrm{B}$, the importance of each segment is illustrated by size and shading. The original system is described in Hansen and Kærk. ${ }^{1}$ The remainder of the paper provides a more detailed description of the most recent developments; of how the dimensions are estimated today and how the basic value dimensions have remained stable over the last seven years.

\section{CONCEPT OF VALUES}

The 'Kompas' (compass) is an attempt to cover as much information as possible about social character in contemporary society using only a limited number of dimensions. In order to understand the system, it is necessary to have a firm grasp of the nature of 'social character'. Riesmann writes:

'The term as thus defined is less inclusive than 'personality', the word which in current usage denotes the total self, with its inherited temperament and talents, its biological as well as physiological components, its evanescent as well as more or less permanent attributes. My reasons for selecting from this complex the abstraction called 'character' is to deal with those components of personality that also play the principal role in the maintenance of social forms - those that are learned in the lifelong process of socialisation'. ${ }^{2}$

Thus, Riesmann emphasises that social character is different from personality, and he adds that it is concerned with only those components of character that are shared among significant social groups, explicitly excluding traits that may relate to differences of temperament in individuals and groups.

Social character is also described in terms of values. It is social values in this sense that the Kompas system attempts to describe. In line with this, Rokeach, 
who promoted the idea of values influencing all human life domains, viewed values as 'centrally held enduring beliefs that guide actions and judgements in specific situations and, beyond immediate goals, in more ultimate states of existence'. ${ }^{3}$

Later, Schwartz and Bilsky, summarised five main features of values, and outlined the common background for social science research on values.

Thus values are:

- concepts or beliefs

- about desirable states or behaviour

- that transcend specific situations,

- guide the selection or evaluation of persons, behaviour and events, and

— ordered by their relative importance.

When describing a phenomenon like social values, different stylistic approaches may be used, and different degrees of detail may be included. A drawing of the human body by Albrecht Dürer is remarkably different from a late drawing of the same object by Henri Matisse. No observer will deny that two such drawings represent the same phenomenon, but they do so with a remarkable degree of difference in style and detail with the Dürer version being much more naturalistic and detailed. With the Kompas system, we are looking for a Matisse-like representation of social character. The inclusion of the details contained in the minute drawing by Dürer requires a much larger number of points to be included in the description. This may be useful for some purposes, thus we have attached a more detailed Kompas Value Map (Table 6) to the Kompas value system.

\section{EARLY VALUE SYSTEMS}

Many measurement systems have been developed for measuring individual value systems. One such set is described in 'The study of values', 5 which was subsequently used in many empirical studies. Another instrument is 'the Rokeach Value Survey', 6 where respondents were asked to rank 36 values in Rokeach terms: 18 instrumental and 18 terminal.

With lifestyle research in the USA as a point of departure, ${ }^{7}$ values and lifestyle $\left(V^{2}\right)^{8}$ and VALS 2 have been used frequently. This system employs value-related statements to be rated on Likert Scales. European systems like Risk and other related systems have further been inspired by this system.

In addition, the list of values (LOV), which was developed at the Survey Research Center at the University of Michigan, ${ }^{9}$ is in common use. The latter has mainly been used in a consumer behaviour context. ${ }^{10}$ The relationships between consumer values and opinions at different levels have been studied with the use of laddering. ${ }^{11}$ Here, the interrelatedness of consumer perceptions at different levels such as basic motives, values, intermediate goals and perceptions is documented.

More recently, the Schwartz Value $(\mathrm{SVI})^{12}$ has been introduced to consumer behaviour research. ${ }^{13}$ Departing from the work by Rokeach this inventory was developed on the basis of several decades of theoretical and empirical work in psychology, social psychology and sociology. Its theoretical starting point is to view values as representing motivations, because they are criteria used by individuals to select and justify actions, based upon which one evaluates people, things, oneself and events. Ten motivational domains of values are suggested and represented across two dimensions. The first dimension reflects opinion to change $v s$. conservation and the other is labelled self-transcendence $v s$. self-enhancement. The system has been 
Table 1: Major dimensions across different value systems

\begin{tabular}{lll}
\hline & 1. Dimension & 2. Dimension \\
\hline VALS & Modern/Traditional & Action-oriented/Principle-oriented \\
RISC & Openness/Resistance to change & Ethics/Hedonism \\
CCA & Change/stability & Material/'Spiritual' works \\
Valuescope & Change to modernity/stability & Pragmatism/Loyalty \\
Kompas & Modern/Traditional & Individually-oriented/Socially-oriented \\
'Danish Attitudes' & Modern/Traditional & Individuality/Collectivism \\
Minerva & Modern/Traditional & Social/Individual \\
\hline
\end{tabular}

applied both in national and cross-cultural studies. ${ }^{14-16}$

Like other value systems used to identify the underlying values guiding choice, the Kompas value system relies upon the definition of values as part of the social character by Riesmann. ${ }^{17}$ The social psychological research referred to here represents the basis for the Kompas system. Other systems have originated in linguistic research, semiology etc. ${ }^{18}$ Value systems such as CCA and Minerva emerged against this background. A discussion of this may be found in Askegaard. ${ }^{19}$ It is remarkable how similar these systems appear when they are analysed in their basic two-dimensional form. The major dimensioning in some of the systems is shown in Table 1.

\section{THE ORIGINAL KOMPAS}

The original Kompas system using the graphic representation illustrated in Figure 1 was (first) introduced by Gallup in Norway. The first Danish Kompas system was developed in 1994 derived from an attitude, interest, behaviour and opinion questionnaire concerning 500 items. This was completed using different quantitative and qualitative techniques. This huge questionnaire was gradually reduced to 62 items focusing on the two dimensions appearing in most other published value research:

- traditional/conservative $v s$. modern/willingness to change
- social orientation, altruistic or open mindedness $v s$. individual, egoistic or closed mindedness.

In the process, it was learned that combining attitudes, interests, behaviour and opinions (AIO) in a simultaneous factor analysis is not recommended. Generally, some dimensions are found reflecting activities, some reflecting interest, some behaviour and still others reflecting opinions. Even though there are relationships between measurements at the three levels in a factor analysis, they do not work well together. Consequently, to define a stable and meaningful value representation in a few dimensions, a choice has to be made whether to use activities, interests or opinions. The Kompas system works with opinions.

Thus, the Kompas system is based upon the measurement of opinions rather than the basic values used in the Rokeach system and interests and activities used in the traditional lifestyle approach. $^{20}$

Moreover, the Kompas system uses only two dimensions. It could be argued that a three-dimensional solution would be more appropriate statistically. In many analyses a third significant dimension appears. Sometimes reflecting egoism vs. altruism. Integrating the Kompas value diagram (Figure 1) into the Kompas system itself makes up, however, for the lack of detail due to focusing on only the two first major dimensions. 


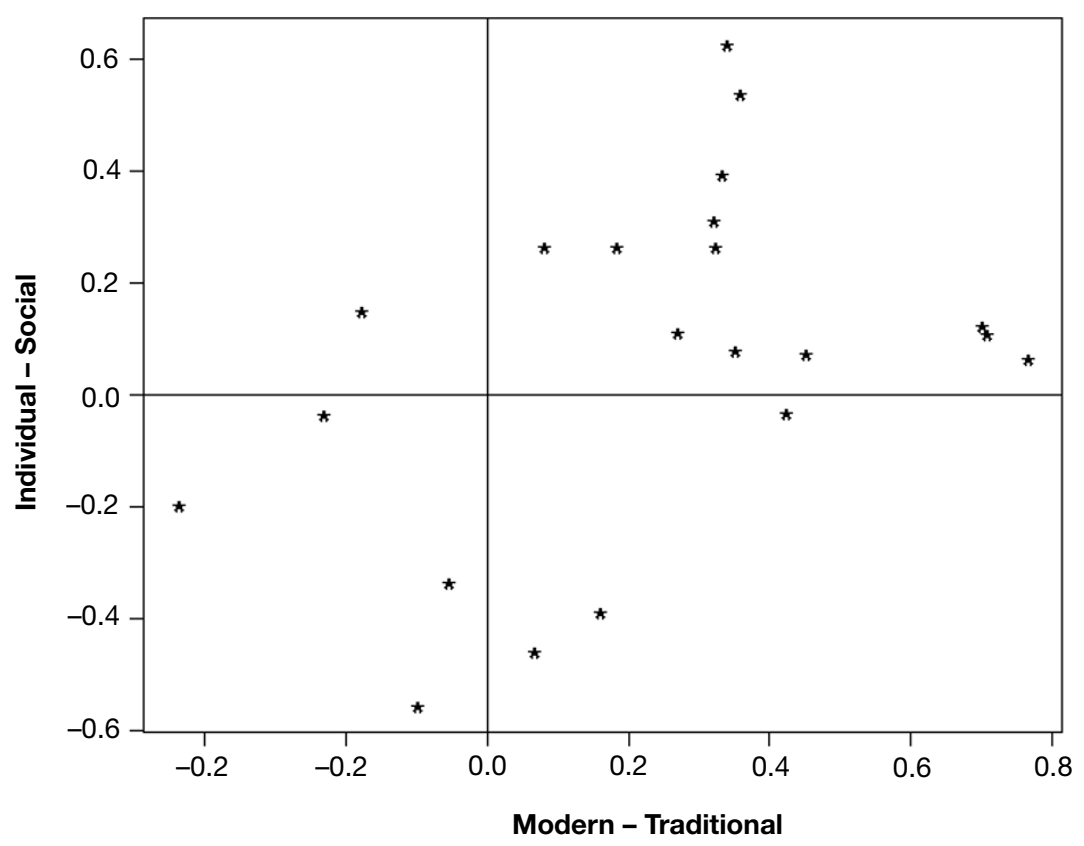

Figure 2 The location of the 23 statements from the original Kompas system in the two-dimensional modern/traditional individual/social space (note two statements fall outside the diagram).

As explained further below, the Kompas system is based upon a relatively limited number of questions selected from a large pool of potential questions. In its early stage it relies upon 23 questions.

Experience gained using the existing Kompas system over the last seven years provides a number of reasons for wanting to modify and improve the system. First, the 23 statements used in the past to identify the two major dimensions are rather unevenly located in the two-dimensional Kompas space. This is illustrated in Figure 2. The reason for this is that, at the time of the construction of the original Kompas, there were relatively few statements in the 'socially/modern corner of the world'.

Secondly, the aim was to examine the effect the changes in values and opinions in society had had over the years on the answers to the questions upon which Kompas was constructed. It is now known that the dimensions along which the evaluations were made have remained very stable, ${ }^{21,22}$ whereas the average scores for the respondents fluctuate from year to year. On the individual/social dimension, fluctuations are minor and in the long run they tend to counteract each other. On the modern/traditional dimension, however, a systematic move in the modern direction can be observed.

A particular reason for the usefulness of Kompas is the sensitivity of the measurements. Sensitivity has been attained by deleting questions of the more obvious nature with which everybody tends to agree. If a person is asked if they think it is a good idea to be 'modern' the majority would agree, and there is not much discrimination among the respondents. If people are asked if IT generates a lot of trouble for them, a much more sensitive response is obtained and, as it turns out, the answers to this question basically reflect the same 
underlying dimension of modern $v s$. traditional orientation.

Over the years, however, the sensitivity of some of the items has decreased, thus in the process of revising Kompas, it seemed natural to look for the effect of such changes.

Even when working with quite large samples, as one begins to construct Kompas illustrations (Figure 1) for small brands in product areas with few consumers, the shape of the Kompas tends to fluctuate from year to year. This can normally be explained as a statistical phenomenon, resulting from small subsamples, but for many users it is still inconvenient. To make it possible to work with Kompas even when smaller samples are involved, it was decided to establish an additional five-segment Kompas. Furthermore, as part of the revision process, alternative Kompas models were identified.

Another reason for revising the items upon which Kompas is computed is the wish to reduce the number of questions needing to be asked. The idea was for it to be possible to reproduce basically the same dimensions with fewer questions as some of the less important questions would be deleted and substituted with a few more efficient ones.

A final reason for looking at the number and selection of statements used for constructing the Kompas was the wish to make the system more flexible for international applications. In

large-scale surveys, the system works in a similar manner throughout the Nordic countries. ${ }^{23}$ Ad hoc applications of the system in modified versions in product areas such as mobile telephone and group travelling suggest that it works quite well in other 'Western' cultures as well.

Applications of the basic system in Poland and Israel have demonstrated that the same dimensions can also be identified in these countries. However, marketers would have to work with a very modified selection of questions. By concentrating on items that are non-specific to the Nordic countries in the revised version, it was hoped the system would be easier to use internationally.

\section{DEVELOPING THE SECOND GENERATION KOMPAS}

Redevelopment and refinement of the system is continuously taking place. A study comparing Schwartz Value Domain and Kompas statements as well as dimensions has been completed. ${ }^{24}$ Following this, a completely new master list of questions was developed, based partly upon focus group interviews and partly upon analyses of sociological theory, news items, existing value measures, etc. In this process, 29 potential topic areas such as environmental issues, EU, religion were identified. For each of these a number of relevant statements were extracted.

To ensure that the new Kompas questionnaire would cover virtually all relevant value/opinion issues in contemporary society, two approaches were used simultaneously. Group discussions were conducted with different age groups in Copenhagen as well as in the provinces. The discussions were structured in such a way as to have the participants reflect on contemporary important opinion/value issues.

Subsequently, the responses were analysed for potential meaningful items. A total list of more than 900 items resulted from this analysis. By examining the initial 900 statements, it was possible to delete approximately 560 due to a similarity with other items, unclear and meaningless formulations etc. All Kompas questions used in the past were included among the resulting 359 items.

Simultaneously, a selection of 
Table 2: Factor loading for the statements with the highest loadings on factor 1 (2 factor solution with 34 variables)

$\begin{array}{lr}\text { If we do not take care, machines will overpower the human race } & 0.787 \\ \text { Changes come about too quickly today } & 0.686 \\ \text { Modern technology makes people more stressed } & 0.682 \\ \text { There is a risk that the Internet will replace social contact between people } & 0.623 \\ \text { Technology prevents people from being creative } & 0.598 \\ \text { I am afraid that traditional family values will totally disappear } & 0.534 \\ \text { Women are exhibited in commercials and magazines in a humiliating way } & 0.521 \\ \text { I feel that Denmark's fundamental values are in danger } & 0.514 \\ \text { There is a big gap between the rich and the poor in today's society } & 0.488 \\ \text { Denmark should do more for the weak and elderly people in society } & 0.440 \\ \text { The welfare society 'kills' personal initiative } & 0.381 \\ \text { The overwhelming air pollution worries me more and more } & 0.350 \\ \text { The Danish national church is an important factor in my daily life } & 0.349 \\ \text { Each home should have a computer } & -0.339 \\ \text { The Christian view of life should be the foundation for Danish law } & 0.310\end{array}$

newspapers and magazines were analysed for important value topics and a number of well-known lifestyle, value and similar questionnaires were subsequently screened. This was done with the purpose of defining a list of major topic areas. This process resulted in a total of 34 such topic areas. Examples are the EC, royal families, refugees.

As a result, the 359 remaining statements were grouped into 34 categories (the original 29 plus the five additional topic areas emerging from working with those of the 359 statements that did not fall in the first 29 topic areas). By concentrating on three statements relating to each of the 34 topic areas and including the original 23 statements, a macro battery of 125 statements emerged.

\section{PRE-TEST AND SCALE CONSTRUCTION}

Using 125 statements together with a number of questions regarding product usage, demography, political voting, etc., a pre-test was carried out with 505 computer assisted telephone interviews (Capi interviews). Based upon the resulting data, a number of statements were deleted due to a lack of discriminative power, ie when more than
70 per cent of the responses fell into one or two categories of the six-point scale used. Other statements were deleted because respondents had obviously had difficulties interpreting their meaning, indicated by 20 per cent or more respondents not answering a question. This left a battery of 75 items: with this battery, a varimax rotated factor analysis using SPSS $^{25}$ was conducted in order to arrive at a meaningful solution using ten dimensions. This discussion will be picked up later.

When using this solution, it was evident that the first two factors closely resembled the expected modern/tradition and social/individual dimensions. Consequently, it was decided to subject the 75 items to a forced two factor varimax rotated solution. Again, the two sought after dimensions emerged. Next, it was decided to measure the highest question loading on each of the two factors and concentrate on these. Two by 17 , or 34 items were selected, and again, a two-factor solution was sought. As an example the resulting rotated first factor, in terms of the highest loading statements, is shown in Table 2. The two-factor solution is also plotted in Figure 3.

In Figure 3 there can be seen a tendency for items to cluster in the 


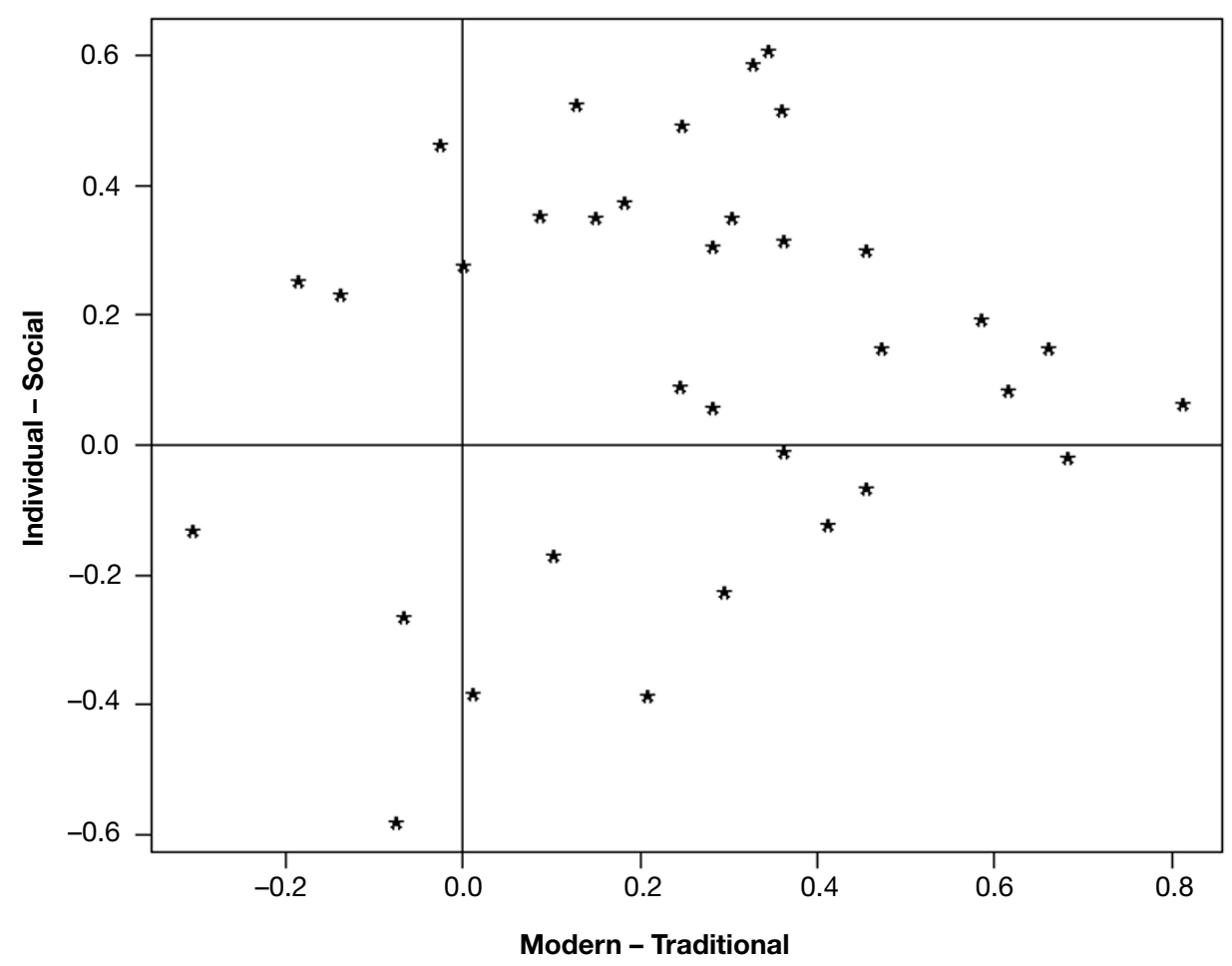

Figure 334 statements plotted along the two major dimensions (individual/social and modern/traditional)

upper right-hand corner (as was the case with the old Kompas system). Therefore, it was decided to reduce the number of questions to 22 by eliminating some of the questions that did not differ much across the dimensions and that were located in clusters with many items.

This 22-item solution, however, turned out not to be very useful as it did not explain variance very well, nor did it discriminate very well across the test variables. Thus, it was decided to go back and include the nine old Kompas statements that had been dropped from the battery in the process of reducing it to 34 statements. Thereby, a new battery of 43 questions emerged. The focus then was on items loading on the two critical dimensions and, once again, a 22-item solution was sought. In the process of comparing the different solutions, four criteria were applied:
- the amount of variance explained by the factors was examined

- the extent to which the results correlated with a solution based upon the old Kompas was tested

- the way in which the items are located in the space defined by the two dimensions (in Figure 3) was examined

- the ability of the segments to discriminate between selected relevant consumer groups such as owners/non-owners of PCs, consumers/non-consumers of organic milk and potatoes, frequency of theatre visits, readers/non-readers of business magazines, involvement/non-involvement in the association for the elderly, voters/non-voters for the Social Democratic party, for the Liberal party and for an extreme right-wing party, respectively. 


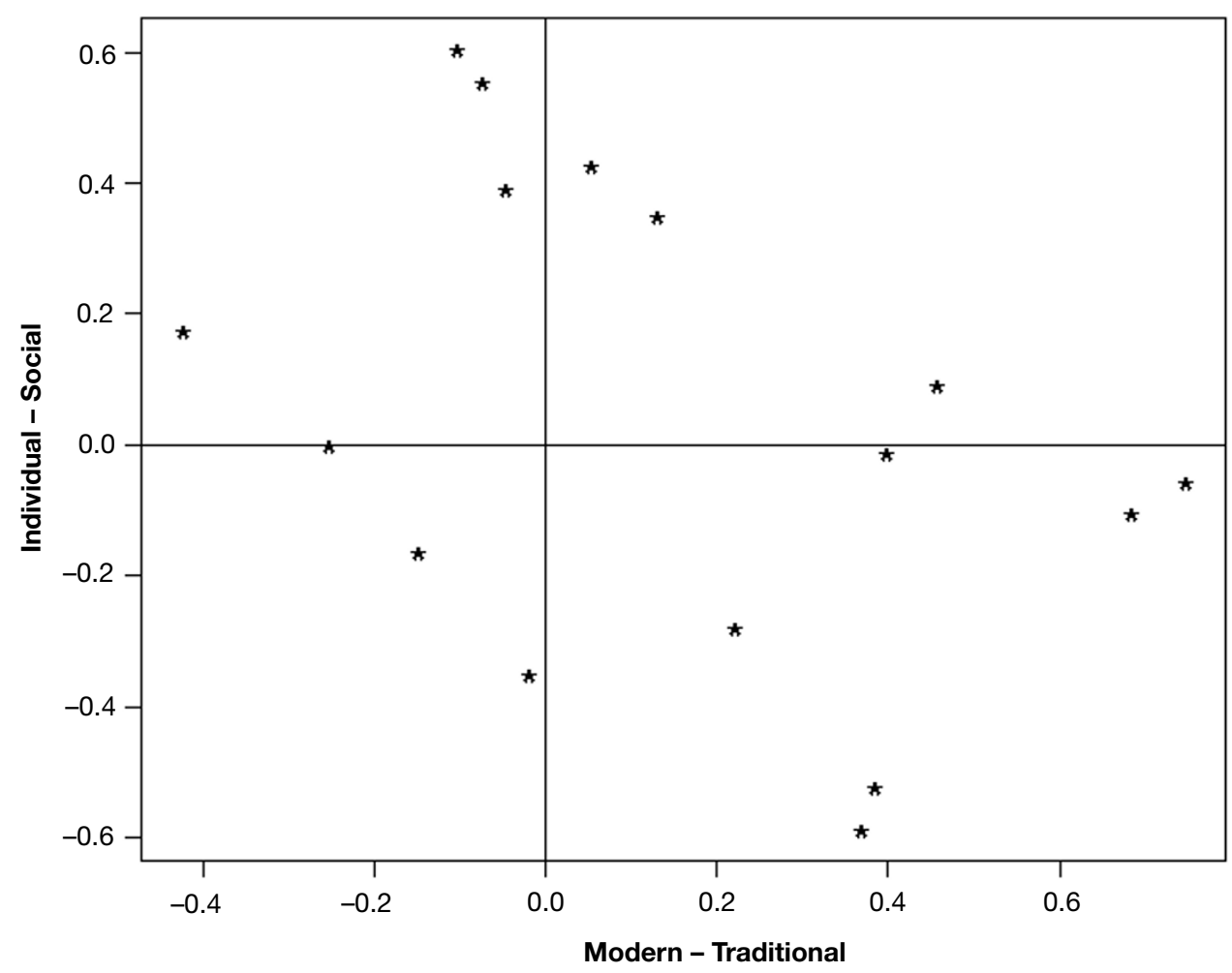

Figure 416 items distributed along the two Kompas dimensions

Based upon this, a 22-item solution was established. It was subsequently tested as to whether it would be possible to delete some of the items without reducing the quality of the solution significantly in terms of the four criteria just described. By doing so a 16-item solution was arrived at. This solution is illustrated in Figure 4. As can be seen, the 16 items chosen distribute themselves nicely in the space defined along the two dimensions. This solution explains 34 per cent of the variance in the battery.

A note of caution is appropriate here. With questionnaire batteries of this kind a certain amount of noise in the responses would be expected. It is quite rare for even a large number of factors to be able to explain more than 60 per cent or so of the variance in such data. To understand this, it is important to realise that the factor analysis approach assumes normally distributed responses. The way in which extreme items have been deleted means that the worst cases of abnormal distribution have been avoided, however, the assumption of normality is far from fulfilled.

Furthermore, a questionnaire of this kind with many items to be rated adds quite a lot of uncertainty to the data. People are just not careful enough with their answers, or they do not perceive the scales identically. Finally, in the construction of the battery, some emphasis was placed on including many, rather than just a few, aspects of relevant opinions in society. Therefore, to be able to account for 33 per cent of the total variance using two factors in the data set described above must, in itself, be said to be more than satisfactory. It is hard to accommodate bi-variate demographic variables such as sex or single/family 
The development of an operational second dimensional value system

Table 3: Classification of respondents based upon the old and new Kompas statements

\begin{tabular}{|c|c|c|c|c|c|c|c|c|c|c|}
\hline OLD KOMPAS NEW KOMPAS & $\mathbf{M}$ & M-I & $\mathbf{I}$ & T-I & $\mathbf{T}$ & T-S & $\mathbf{S}$ & M-S & C & TOTAL \\
\hline Modern & 37 & 12 & & & & & & 4 & 7 & 60 \\
\hline Modern-individual & 7 & 31 & 15 & & & & & & & 53 \\
\hline Individual & & 5 & 21 & 11 & 1 & & & & 9 & 47 \\
\hline Traditional-individual & & & 8 & 44 & 13 & 1 & & & & 66 \\
\hline Traditional & & 1 & 1 & 10 & 41 & 10 & & & 9 & 72 \\
\hline Traditional-social & & & & & 7 & 26 & 10 & & 1 & 44 \\
\hline Social & 2 & & & & 1 & 12 & 34 & 6 & 6 & 61 \\
\hline Modern-social & 10 & & & & & & 9 & 33 & & 52 \\
\hline Centre & 4 & 2 & 2 & 6 & 6 & 3 & 3 & 6 & 26 & 58 \\
\hline Total & 60 & 51 & 47 & 71 & 69 & 52 & 56 & 49 & 58 & 513 \\
\hline
\end{tabular}

household, which, in turn, account for much of the variance in any set of observations of human behaviour.

The intention was not to reconstruct the new Kompas as a replica of the old, but to improve it. Having said that, the expectation was that the same basic dimensions for the model would be found using the new Kompas. To examine this hypothesis, the classification of respondents in the old and the new Kompas solutions have been analysed in Table 3. It appears that very few observations in the new Kompas system fall into categories that do not correspond with, or at least resemble, the old Kompas system.

The fourth criterion of usefulness for the new Kompas was its ability to discriminate between relevant consumer groups. Ideally, this aspect should be as good or, preferably, better than that of the old Kompas.

The result of this comparison is illustrated in Table 4. Table 4 reads as follows: in the old Kompas 86.9 per cent of the consumers in the modern segment own a PC. In the new Kompas 87.9 per cent of the same segments do so. On the contrary, in the traditional individual segment 31.8 and 38.6 per cent in the old and new Kompas respectively had a stationary computer. Similarly, the percentage of consumers who use organic milk in the segment with the highest consumption (traditional and social-oriented) is 54.8 in the old Kompas and 53.4 in the new. The similarly low percentages for organic milk are found in the traditional individual segment with 4.4 and 5.1 per cent respectively.

In addition, the Kompas discriminates very well between all the items tested. That is, the coverage of the highest segment compared with that of the lowest segment is very different. Based on this discovery, it was decided to use the 16-item solution identified above.

\section{THE NINE-SEGMENT SECTOR}

In principle, each individual in the sample was assigned to one of the nine segments depending on her/his score along the two dimensions. The way in which this was done in the old Kompas is shown in Figure 5. Here, vertical and horizontal lines are placed around the centre so that nine almost equal segments result. Since the factor scores are normally distributed along both dimensions, it results in an almost symmetrical solution.

In the new Kompas, the problem was approached in a slightly different manner. The neutral central segment is defined as a circle and the eight surrounding segments are defined with the use of radial lines pointing in different directions. The radius of the centre circle is set to the $1 / 9$ quantile of a $\mathrm{chi}^{2}$ 
Table 4: Segments with the highest and lowest frequency of use or possession in the old and new Kompas

\begin{tabular}{lccl}
\hline & Old \% & New \% & Segment \\
\hline PC stationary (max) & 86.9 & 87.9 & $\mathrm{M}-\mathrm{MS}$ \\
PC stationary (min) & 31.8 & 38.5 & $\mathrm{~T}-\mathrm{TI}$ \\
Organic milk daily (max) & 54.8 & 53.4 & $\mathrm{~S}-\mathrm{MS}$ \\
Organic milk daily (min) & 4.4 & 5.1 & $\mathrm{I}-\mathrm{TI}$ \\
Potatoes daily (max) & 37.4 & 37.6 & $(\mathrm{I}, \mathrm{T})-\mathrm{TI}$ \\
Potatoes daily (min) & 16.3 & 13.1 & $\mathrm{~S}-\mathrm{MS}$ \\
Goes to the theatre never (max) & 62.2 & 67.5 & $\mathrm{I}-\mathrm{TI}$ \\
Goes to the theatre never (min) & 16.3 & 17.2 & $\mathrm{~S}-\mathrm{MS}$ \\
Reads 'Money and private economy' (max) & 18.2 & 16.5 & $\mathrm{M}-\mathrm{MI}$ \\
Reads 'Money and private economy' (min) & 4.5 & 4.5 & $\mathrm{C}-\mathrm{C}$ \\
Reads 'The elderly's cause' (max) & 24.3 & 23.9 & $\mathrm{~T}-\mathrm{TI}$ \\
Reads 'The elderly's cause' (min) & 4.0 & 3.3 & $\mathrm{M}-\mathrm{MI}$ \\
Votes for the Social Democratic party (max) & 43.3 & 40.7 & $\mathrm{~T}-\mathrm{TS}$ \\
Votes Liberal (max) & 41.2 & 44.0 & $\mathrm{M}-\mathrm{Ml}$ \\
Danish People's Party (max) & 16.5 & 12.0 & $\mathrm{I}-\mathrm{MI}$ \\
\hline
\end{tabular}

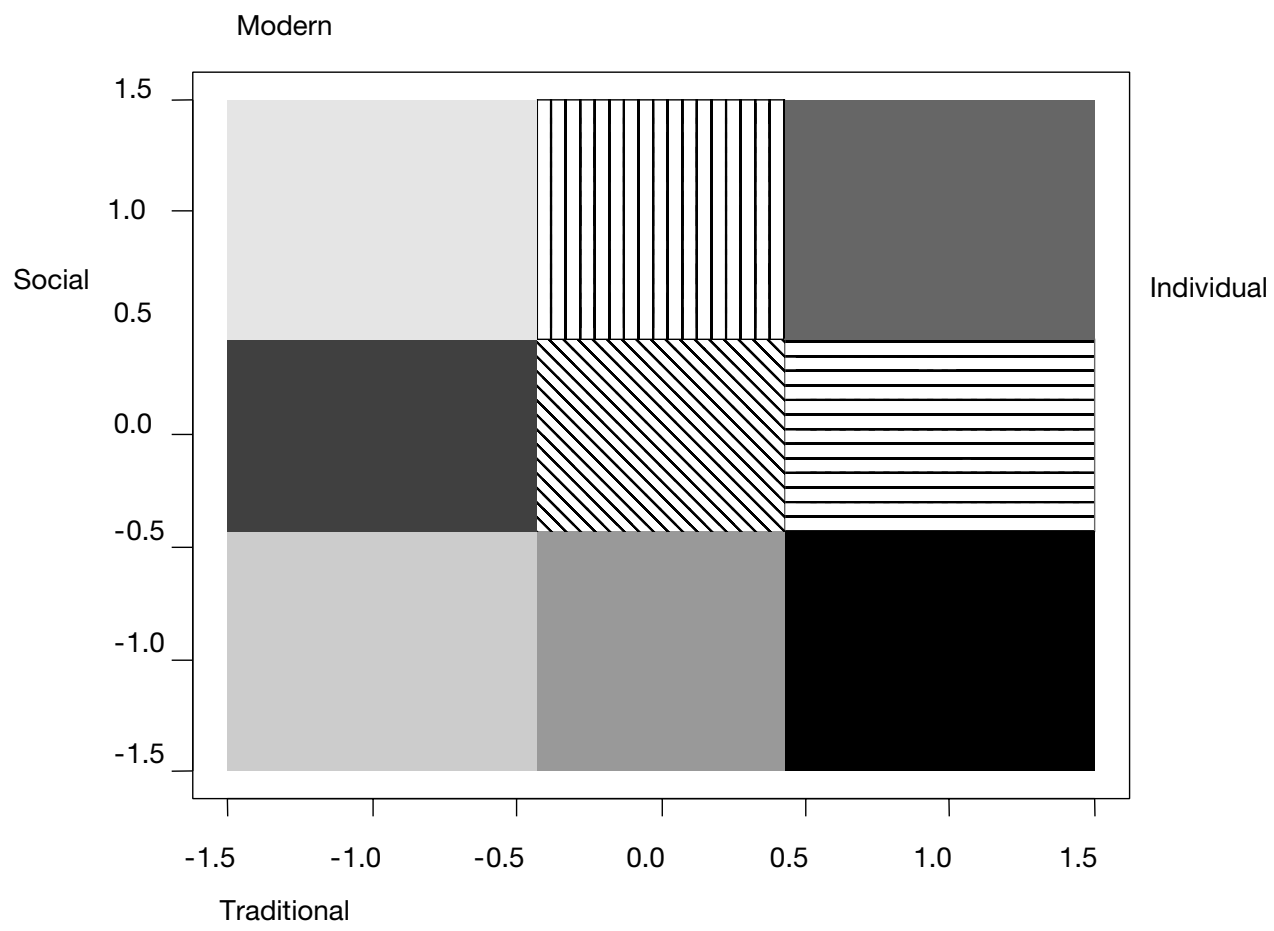

Figure 5 Definition of nine segments in the old Kompas

distribution. This guarantees

asymptotically and equally-sized

segments. Since the assumption about

normality does not hold true completely, however, there will be slight differences in the size of the segments. Figure 6 illustrates how the segments are defined. Apart from its logical appeal, the new solution also makes it more meaningful to construct reduced or five-segment solutions.

In this connection, it should also be noted that some of the cases that move from one segment to another in Table 5 do so precisely because of the change in the definition of the segments (as 


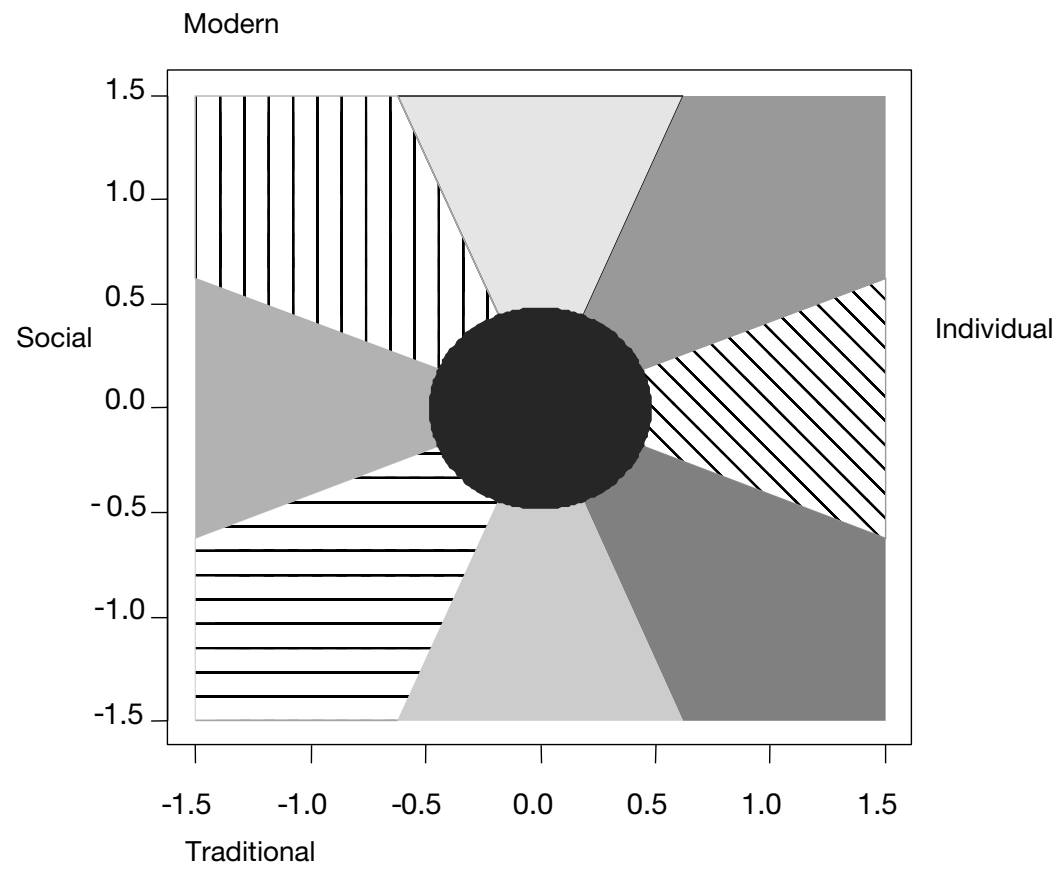

Figure 6 New definition of the nine segments

illustrated in Figure 5 and 6). Some of the respondents located in the border area of two segments, Figure 5, may also appear in a neighbouring segment, Figure 6.

\section{THE FIVE-SEGMENT SOLUTION}

A five-segment solution is desirable since in some instances the number of respondents in the analysed target group is too small to give stable description in nine segments.

The five-segment Kompas can be constructed in two ways: either as a 'diagonal' Kompas as shown in Figure 7 or as a Maltese Cross Kompas as seen in Figure 8 . Both solutions are, of course, based upon the same 16 questions as the nine-segment Kompas. Therefore, the most important criterion for judging the usefulness of either system is the discriminative power in the resulting segmentation. After this analysis was completed using the nine-segment Kompas, it turned out that neither of the two solutions was preferable to the other.
The two function very differently in different cases. In some cases, one is very discriminating while the other is much less discriminating and vice versa. For that reason, it was decided to leave it optional whether to use either the diagonal or the Maltese Cross five-segment solution depending upon the product area in question.

The database, which the client may use, includes assignment of the belongings of each respondent to a particular segment in each of the three different segmentations.

The way in which the five-segment Kompas system discriminates can be illustrated with a Kompas for liberal voters as shown in Figure 9B. Here, the concentration of voters in the modern individual segment $(9 \mathrm{~A})$ is not surprising.

\section{THE EIGHT-STATEMENT SOLUTION}

For use in ad hoc surveys and in cases when the questionnaire's capacity is 


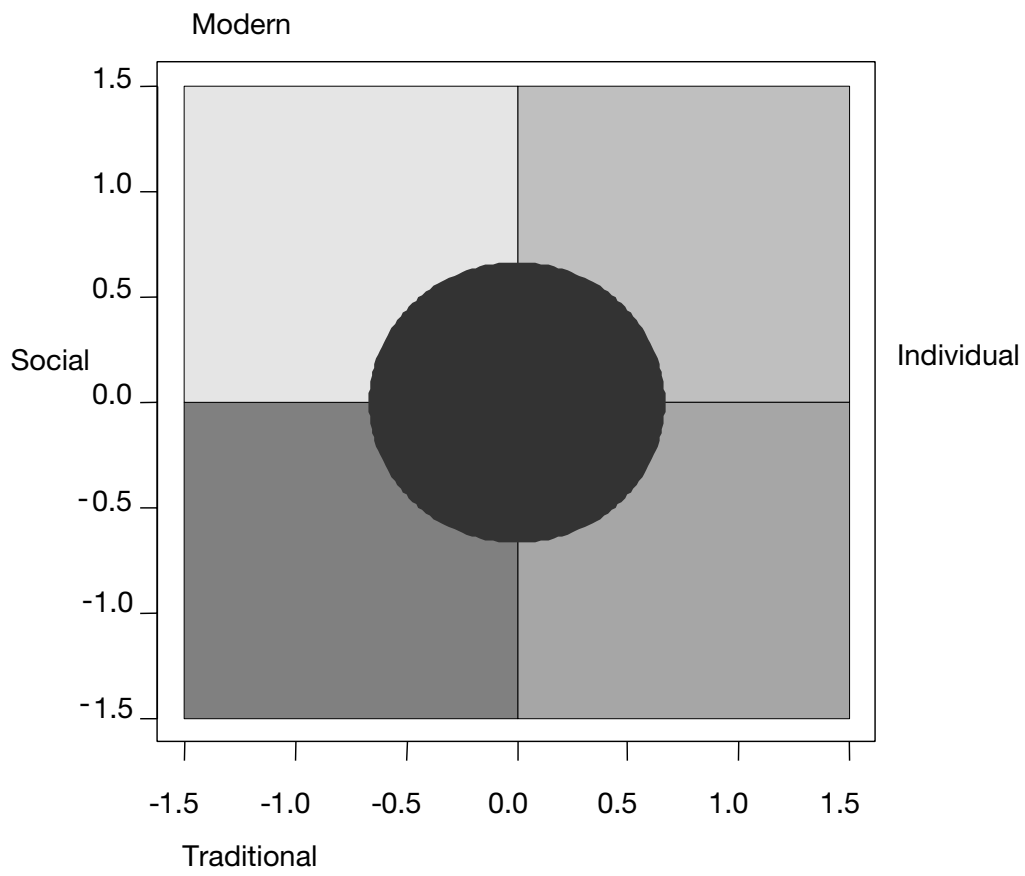

Figure 7 Diagonal five-segment Kompas

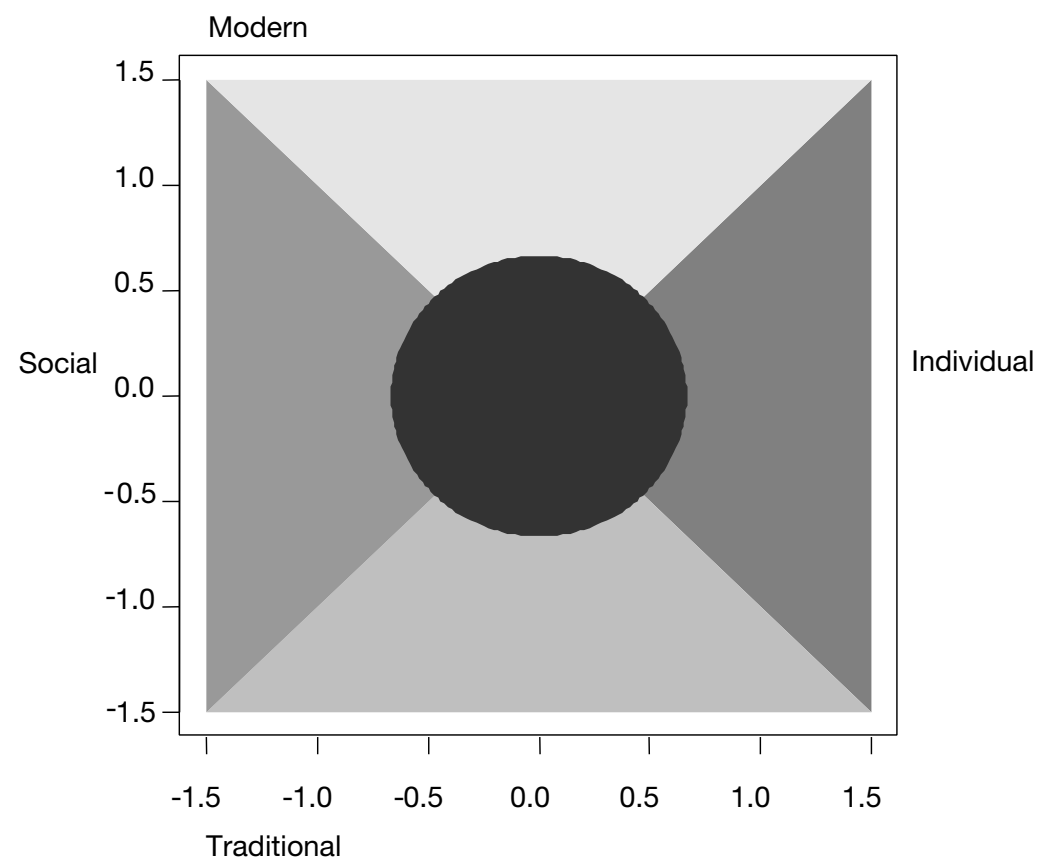

Figure 8 Maltese five-segment Kompas 

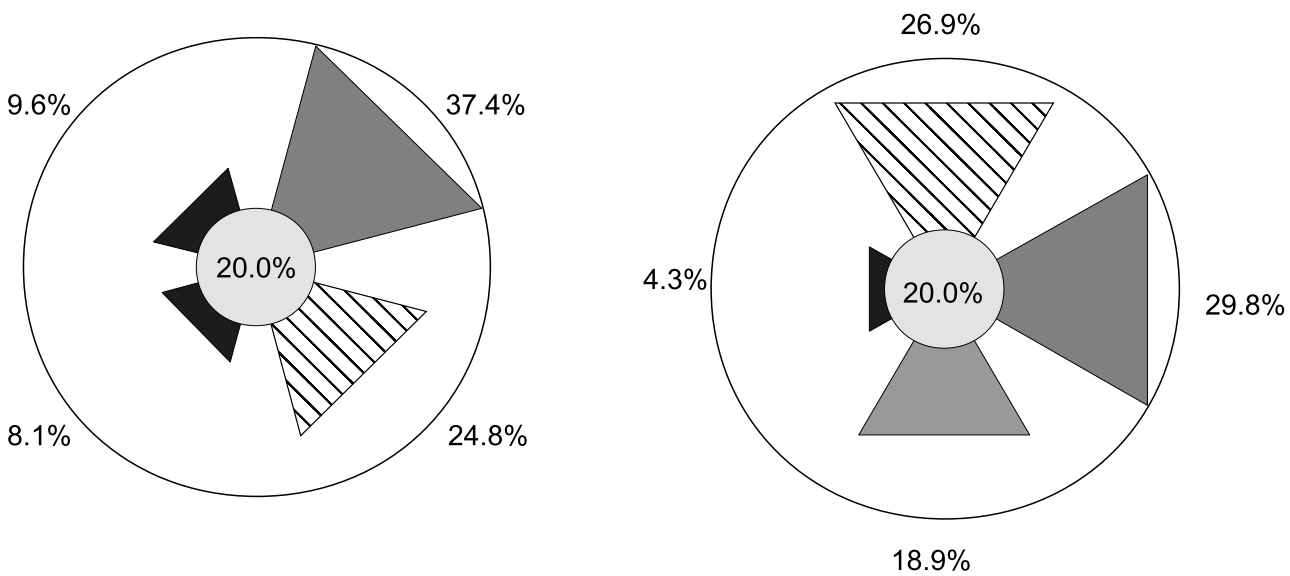

Figure 9 Diagrams of liberal voters in diagonal and Maltese five-segment Kompasses for the Danish general election in 1998

limited, a solution based on only eight statements was constructed. Here, statements are selected in pairs from the 16-statement solution (Figure 4) so that they represent the two dimensions' positive and negative poles as well as possible. In terms of discriminative power, the eight-statement solution performs almost as well as the 16-statement solution. That is, in most cases 90-95 per cent of the respondents are placed in corresponding segments.

\section{THE KOMPAS VALUE MAP}

As suggested several times in the preceding pages, the different batteries contain an enormous amount of information in addition to what is extracted in the relatively simple two-dimensional Kompas solution. To explore this further, it was decided to look at factor analysis solutions across more dimensions for the 125- and the 42-statement batteries. (See 'Pre-test and scale construction' section)

The 125-item solutions are based on a selection of statements that are representative of the 34 opinion areas that were initially developed and into which the even larger number of statements from the qualitative research were grouped. It turns out that this solution provides very interesting results in terms of ten dimensions describing important aspects of contemporary Danish (and probably also Nordic) public concerns. The solution with the four highest loading items in each factor is shown in Table 6.

The distribution of the positive and negative poles of each of the ten values are shown in Figure 10. This solution, however, is based on 125 questions, among which, as discussed earlier, some have limited discriminative power. When a ten-factor solution is attempted with the 43-item battery used earlier, it turns out that it almost perfectly reproduces the ten-factor solution based upon the 125 items. A couple of the factors collapsed, however, and two of the factors in the ten-factor solutions, based on the 125 items, do not appear in the 43-item solution, since the questions upon which they load were deleted in the process of moving from 125 to 43 items. If, however, the 43 -item battery is expanded selectively with a total of 12 items from the original 125 items, keeping in mind the above-mentioned shortcomings, it turns out that the same 
Table 5: Classification of respondents based upon full and reduced Kompas battery. Of the respondents, 62 per cent fall into the same category, and most of the remaining 38 per cent fall into neighbouring segments. Note that there is an equal distribution between the two sides of the neighbouring segments that the respondents fall into, ie the mini solution is not rotated compared to the full solution.

\begin{tabular}{|c|c|c|c|c|c|c|c|c|c|c|}
\hline $\begin{array}{l}\text { Mini Kompas } \\
\text { Kompas }\end{array}$ & $\mathbf{M}$ & M-I & $\mathbf{I}$ & T-I & $\mathbf{T}$ & T-S & $\mathbf{S}$ & M-S & C & TOTAL \\
\hline Modern & 43 & 7 & & & & & 2 & 7 & 4 & 63 \\
\hline Modern-individual & 2 & 36 & 8 & 1 & & & & & 9 & 56 \\
\hline Individual & & 5 & 23 & 17 & 1 & & & & & 46 \\
\hline Traditional-individual & & & 12 & 39 & 14 & & & & & 65 \\
\hline Traditional & & & 2 & 13 & 41 & 7 & & & 1 & 64 \\
\hline Traditional-social & 1 & & 1 & & 6 & 39 & 7 & & 7 & 61 \\
\hline Social & 1 & 1 & & & & 2 & 35 & 5 & 1 & 45 \\
\hline Modern-social & 11 & 2 & & & & & 9 & 34 & 6 & 62 \\
\hline Centre & 2 & & & 1 & 7 & 4 & 3 & 3 & 30 & 51 \\
\hline Total & 60 & 51 & 47 & 71 & 69 & 52 & 56 & 49 & 58 & 513 \\
\hline
\end{tabular}

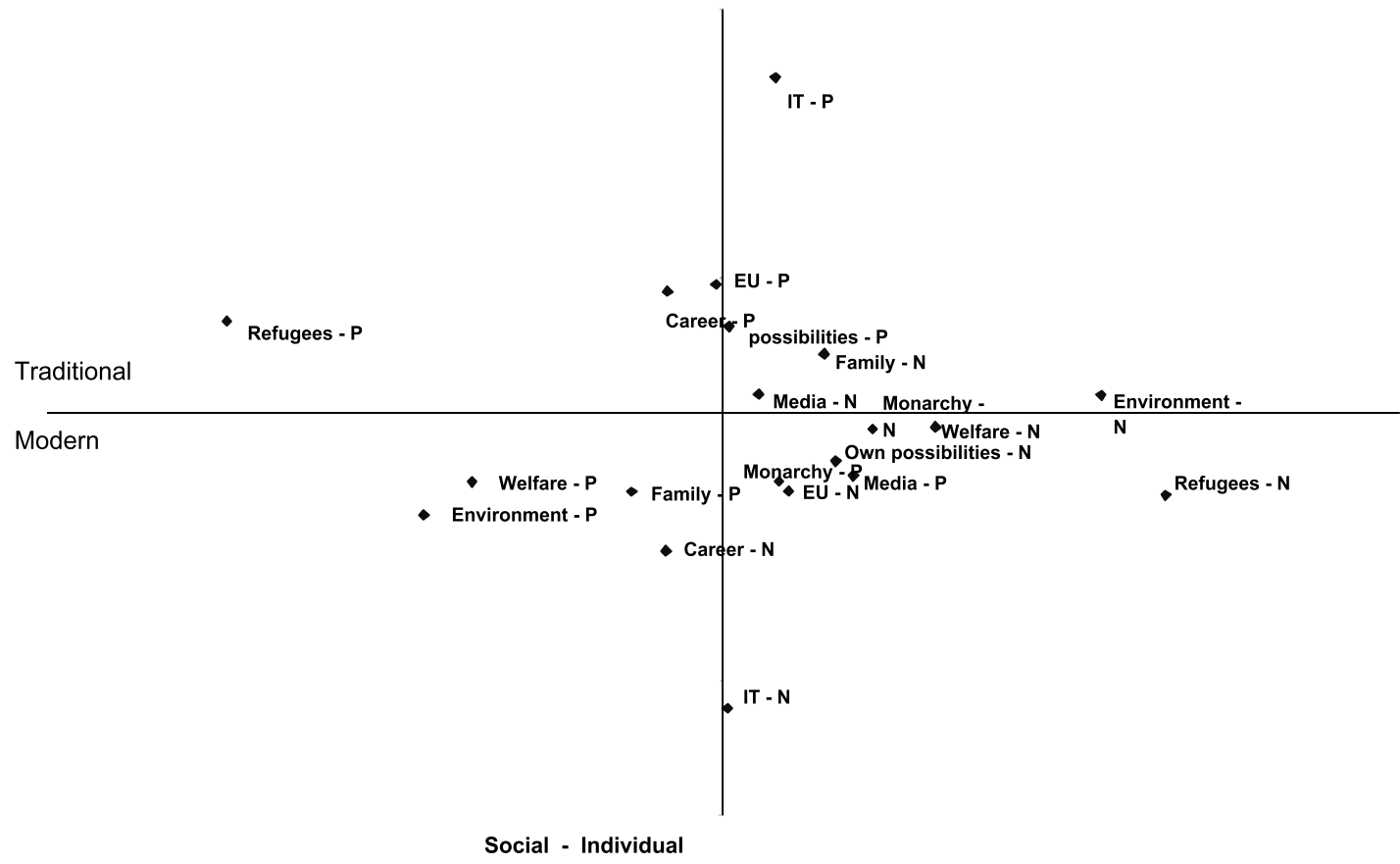

Figure 10 Kompas value map. 10+10 extreme values plotted in a regular Kompas diagram. (For terminology see Table 6)

solutions as those using the aforementioned 125 items can basically be established using these 55 items.

It should also be mentioned that the collective system allows for an interesting combined use of product-specific Kompasses as well as the value chart or items from the value chart. In the interactive IT-applications of the system for example, it is possible to select single questions of particular relevance for the product being analysed to see where they are located in relation to the Kompas segment of the product in question. If, for example, liberal voters are the group of interest, some of the questions that will eventually characterise these segments may be sought.

In general, any of the 45 statements may be picked and have their location 
Table 6: The four highest loading questions in a ten-factor value solution based upon 125 statements (the Kompas Value Map)

\begin{tabular}{|c|c|c|c|c|}
\hline $\begin{array}{l}\text { Refugee/immigrant } \\
\text { issues }\end{array}$ & $\begin{array}{l}\text { Things become } \\
\text { uncertain and } \\
\text { disturbed with the } \\
\text { presence of too } \\
\text { many non-Danes }\end{array}$ & $\begin{array}{l}\text { Too little is done for } \\
\text { refugees in Denmark }\end{array}$ & $\begin{array}{l}\text { There must be tough } \\
\text { demands on } \\
\text { refugees and } \\
\text { immigrants who } \\
\text { want to settle in } \\
\text { Denmark }\end{array}$ & $\begin{array}{l}\text { Immigration laws } \\
\text { should be } \\
\text { tightened severely }\end{array}$ \\
\hline IT & $\begin{array}{l}\text { We have to take } \\
\text { care that modern } \\
\text { technology is not } \\
\text { taking over the } \\
\text { power from human } \\
\text { race }\end{array}$ & $\begin{array}{l}\text { Modern technology } \\
\text { and computers are } \\
\text { frightening }\end{array}$ & $\begin{array}{l}\text { Everything changes } \\
\text { too fast today }\end{array}$ & $\begin{array}{l}\text { There is a risk that } \\
\text { the Internet will } \\
\text { replace social } \\
\text { contact between } \\
\text { people }\end{array}$ \\
\hline Environment & $\begin{array}{l}\text { I would buy more } \\
\text { bio-organic food if it } \\
\text { was available }\end{array}$ & $\begin{array}{l}\text { I always buy } \\
\text { environmentally } \\
\text { friendly products if I } \\
\text { can }\end{array}$ & $\begin{array}{l}\text { The air pollution } \\
\text { worries me more and } \\
\text { more }\end{array}$ & $\begin{array}{l}\text { I always read } \\
\text { declarations before } \\
\text { I buy groceries }\end{array}$ \\
\hline Welfare & $\begin{array}{l}\text { Pay-per-use taxes } \\
\text { are necessary in the } \\
\text { Danish health sector }\end{array}$ & $\begin{array}{l}\text { Unions have too } \\
\text { much power in } \\
\text { Denmark }\end{array}$ & $\begin{array}{l}\text { I would rather pay } \\
\text { less in tax and pay } \\
\text { for more things } \\
\text { myself }\end{array}$ & $\begin{array}{l}\text { It should be } \\
\text { voluntary to be a } \\
\text { member of a union }\end{array}$ \\
\hline EU & $\begin{array}{l}\text { Denmark should be } \\
\text { a full member of the } \\
\text { EU }\end{array}$ & $\begin{array}{l}\text { Denmark should } \\
\text { focus more on } \\
\text { Nordic cooperation } \\
\text { than European } \\
\text { cooperation }\end{array}$ & $\begin{array}{l}\text { Denmark has no } \\
\text { possibilities of } \\
\text { influencing decisions } \\
\text { in EU }\end{array}$ & $\begin{array}{l}\text { EU pays more } \\
\text { attention to } \\
\text { industry than to } \\
\text { the users }\end{array}$ \\
\hline Media & $\begin{array}{l}\text { Watching television } \\
\text { is my greatest } \\
\text { pleasure in my spare } \\
\text { time }\end{array}$ & $\begin{array}{l}\text { Commercials are } \\
\text { entertaining and } \\
\text { informative }\end{array}$ & $\begin{array}{l}\text { I get most of my } \\
\text { information from the } \\
\text { local paper }\end{array}$ & $\begin{array}{l}\text { The Danish school } \\
\text { and education } \\
\text { system improves } \\
\text { every year }\end{array}$ \\
\hline Egocentric & $\begin{array}{l}\text { The media are too } \\
\text { focused on } \\
\text { sensational news }\end{array}$ & $\begin{array}{l}\text { It is OK to smoke } \\
\text { and drink if it } \\
\text { increases your } \\
\text { quality of life }\end{array}$ & $\begin{array}{l}\text { Men are often } \\
\text { overlooked in the } \\
\text { sex debate }\end{array}$ & $\begin{array}{l}\text { Gene technology is } \\
\text { the key in curing } \\
\text { many diseases }\end{array}$ \\
\hline $\begin{array}{l}\text { Monarchy and } \\
\text { church }\end{array}$ & $\begin{array}{l}\text { The Danish church } \\
\text { plays an important } \\
\text { part in my daily life }\end{array}$ & $\begin{array}{l}\text { Danish laws should } \\
\text { be based on the } \\
\text { Christian way of life }\end{array}$ & $\begin{array}{l}\text { The monarchy is a } \\
\text { great advantage for } \\
\text { the Danish industry }\end{array}$ & $\begin{array}{l}\text { 'Moonlighting' is } \\
\text { unacceptable }\end{array}$ \\
\hline Family & $\begin{array}{l}\text { I would like to spend } \\
\text { more time with my } \\
\text { family }\end{array}$ & $\begin{array}{l}\text { Family is my highest } \\
\text { priority }\end{array}$ & $\begin{array}{l}\text { The industry has } \\
\text { little understanding } \\
\text { of the needs of } \\
\text { families with } \\
\text { children }\end{array}$ & $\begin{array}{l}\text { There are too few } \\
\text { women in leading } \\
\text { positions in } \\
\text { Denmark }\end{array}$ \\
\hline Career & $\begin{array}{l}\text { Career is important } \\
\text { for my quality of life } \\
\text { and identity }\end{array}$ & $\begin{array}{l}\text { It is important for } \\
\text { me to be successful }\end{array}$ & I like to own things & $\begin{array}{l}\text { The home needs a } \\
\text { computer }\end{array}$ \\
\hline
\end{tabular}

plotted. Figure 11 displays statements for each of the ten value dimensions chosen together with four items particularly related to organic products. In Figure 12, users of organic milk are shown. By comparing Figure 11 and Figure 12 it will be seen that organic statements are concentrated in the segment where organic milk drinkers dominate. This procedure also makes it possible to identify a relatively limited number of screening questions to be used in qualitative research representing particular segments and products. By picking the central statements in the critical segment, the chances of proper screening of the 


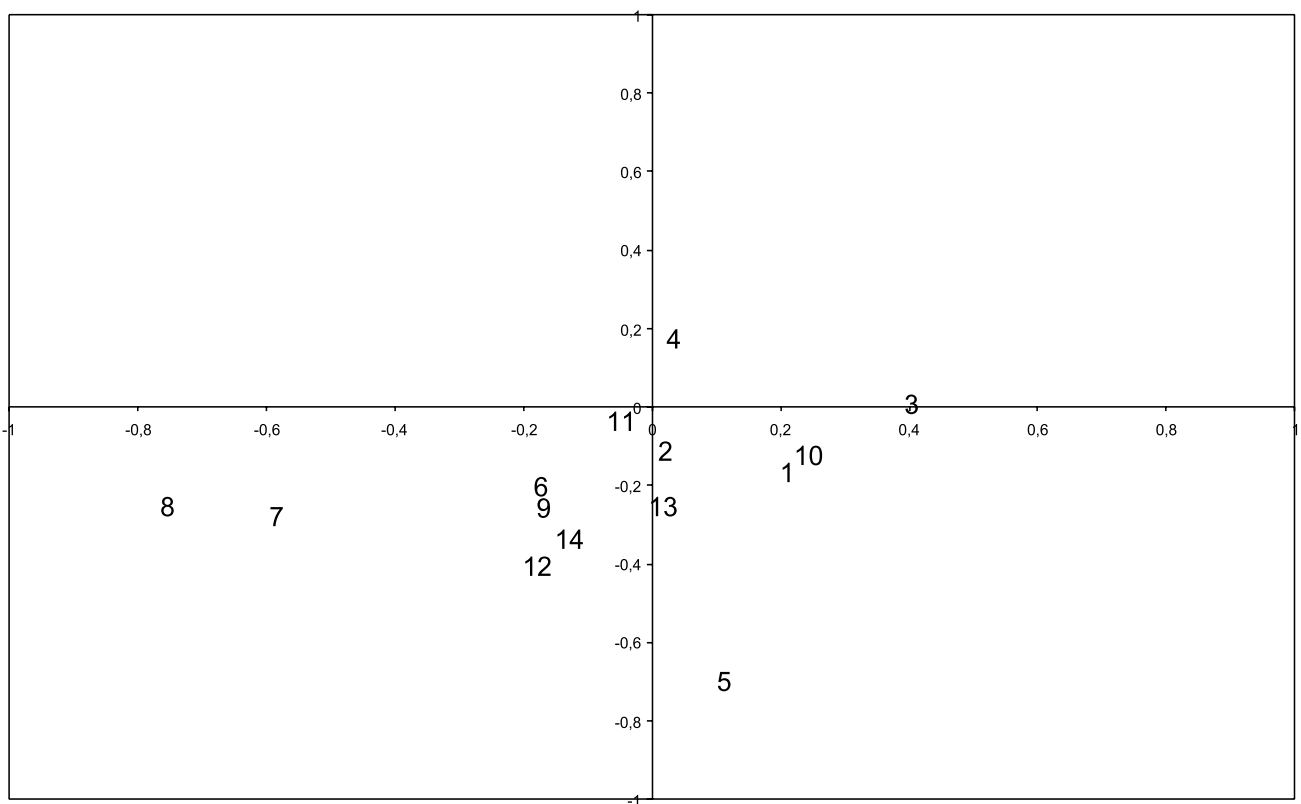

Figure 11 Mean score of respondents who agree partially or completely with the 14 selected items. The items are listed in Table 7.

Table 7

1 We should have higher demands on refugees who want to settle in Denmark

2 Family is my highest priority

3 I would rather pay less in tax and pay for more things myself

4 Denmark should be a full member of the EU

5 Everything changes too quickly today

6 I read the declarations when I buy food

7 I always buy environmentally friendly products if I can

8 I would buy more bio-organic food if it was available

9 Air pollution worries me more and more

10 Commercials are entertaining and informative

11 The media is too focused on sensational news

12 My career is an important part of my quality of life and identity

13 The monarchy does wonders for Danish industry

14 I like to try food from different countries

respondents used in qualitative research will be increased.

With Kompas it is also possible to specify the nature of the users of specific brands. This is shown for Coca Cola in Figure 13. Here it is seen how the brand finds its users, particularly among the modern-individual group.

Car markets are often segmented based on price/income, type of car (sedan/van etc) and similar criteria, but target groups may also be seen as those who are considering a particular brand. How such target groups may differ widely is shown in Figures $14 \mathrm{a}$ and $\mathrm{b}$ where Kompas for those who would consider Citroën or Audi in their next car purchase with Audi purchasers being much more individually oriented.

It can be seen how different brands have different individuals among their potential buyers. 


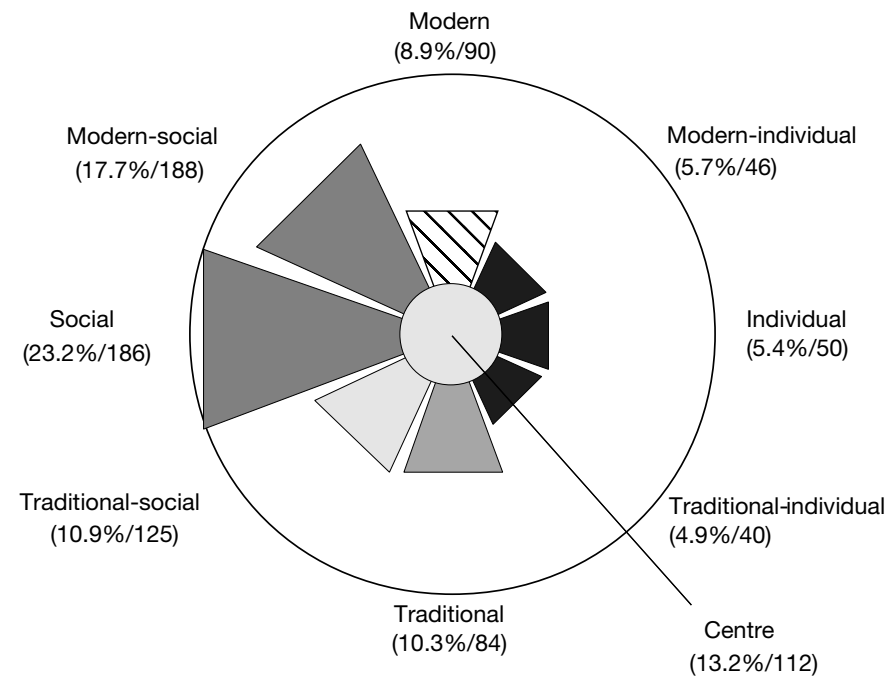

\section{Gallup Kompas}

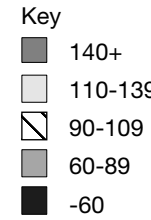

Figure 12 Distribution of people who drink organic milk daily

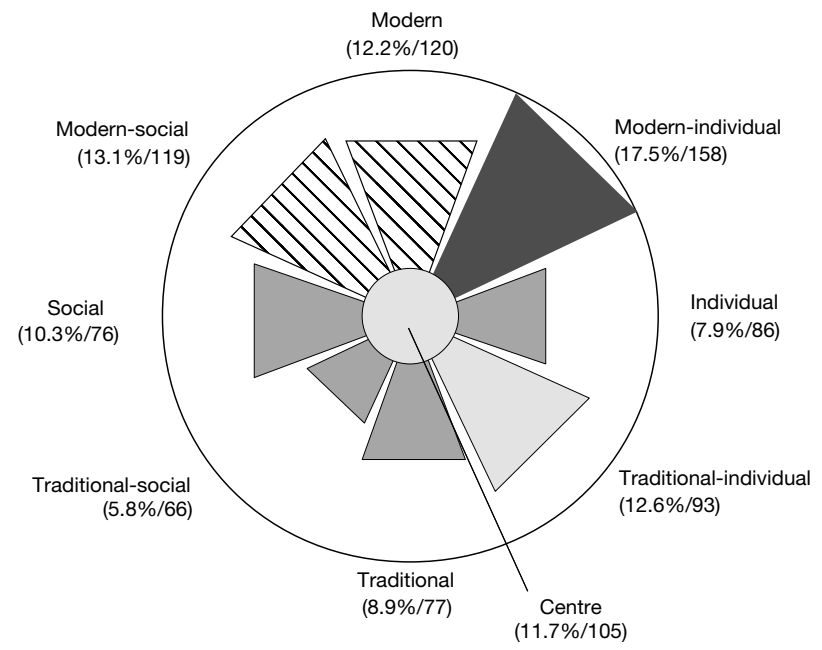

Gallup Kompas

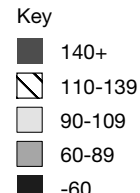

Figure 13 Coca Cola users (most frequently used)

\section{CONCLUSION}

This paper has presented the development of the new Kompas System 2000 and suggested a few of its applications. The system is so rich in application uses and the amount of data available so large that several books could be written on its applications both in terms of methodology and illustrative case studies. In the future, a lot of such cases will emerge. So far, in the spring of 2001, the whole system has been tested 


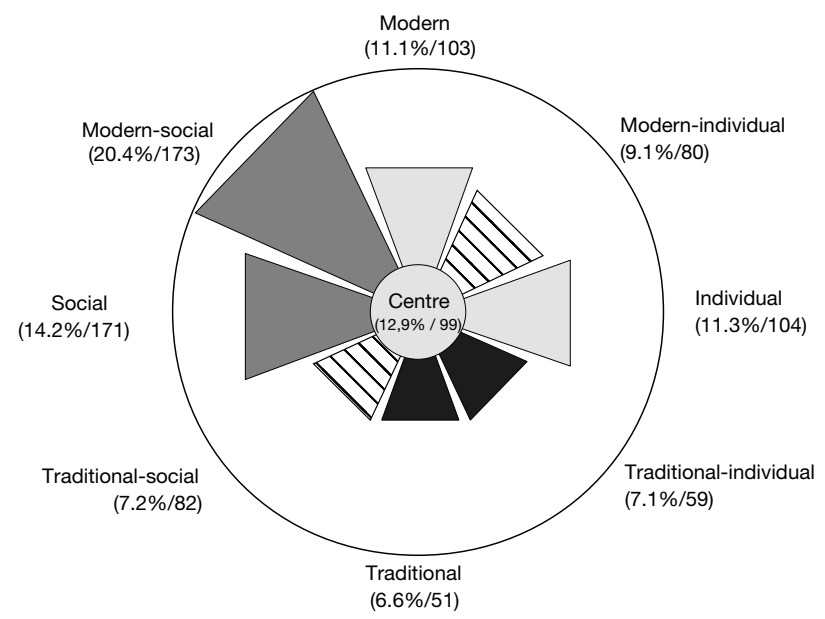

\section{Gallup Kompas}

Figure 14a Consumers who would consider Citroën in their next car purchase

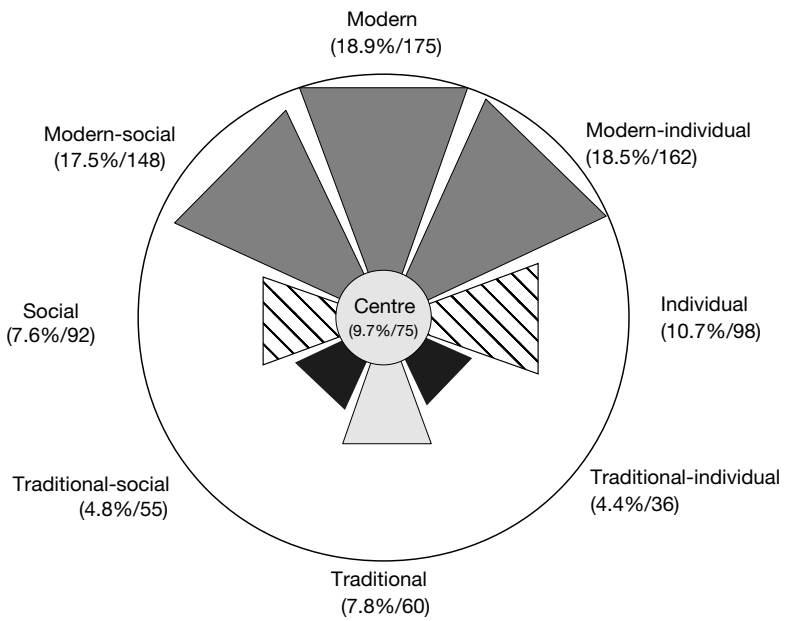

\section{Gallup Kompas}

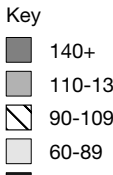

Figure 14b Consumers who would consider Audi in their next car purchase

and validated using a sample of 2000 randomly selected respondents and thus its discriminative power, in terms of being able to profile brand users, has also been documented. The system in its new form has been available from the Danish marketing media index since autumn
2001 and hopefully it will be available in many other countries in the future too.

\section{Acknowledgment}

This paper incorporates input from a large number of colleagues, among whom the author would like to thank: consultant Lykke Nordblom, consultant Birgitte 
Høg, Director Morten Kromann Larsen and psychologist Anette B. Bangsgaard.

\section{References}

1 Hansen, F. and Kærk, A. (1997) 'Value dimensions - are there really that many?', proceedings from the 49th Annual Esomar Conference, Istanbul, September.

2 Riesmann, D. (1950) 'The lonely crowd', Yale University Press, New Haven.

3 Rokeach, M. J. (1968) 'Beliefs, attitudes, and values', Jossey Bass, San Francisco, CA.

4 Schwarz, S. H. and Bilsky, W. (1987) 'Toward a universal psychological structure of human values', Journal of Personality and Social Psychology, Vol. 53, No. 3, pp. 550-562.

5 Vernon, P. and Allport, G. W. (1931) 'A test for personal values' Journal of Abnormal and Social Psychology, Vol. 26, pp. 231-248.

6 Rokeach, M. J. (1973) 'The nature of human values', Free Press, New York, NY.

7 Plummer, J. T. (1974) 'The concept and application of life style segmentation', Journal of Marketing, Vol. 38, January, pp. 33-37.

8 Mitchell, A. (1983) 'Nine American lifestyles: Who we are and where we are going', MacMillan, New York.

9 Kahle, L. R. E. (1983) 'Social values and social change: Adaptation to life in America', Praeger, New York.

10 Homer, P. M. and Kahle, L. R. (1988) 'A structural equation test of the value-attitude-behavior hierarchy', Journal of Personality and Social Psychology, Vol. 54, No. 4, pp. 638-646.

11 Gutman, J. and Reynolds, T. J. (1986) 'Coordinating assessment to strategy development: An advertising assessment paradigm based on the MECCAS model', Olson, I. J. and Sentis, K. (eds) 'Advertising and consumer psychology 3', pp. 242-258. Praeger, New York.

12 Schwartz, S. H. (1992) 'Universals in the content and structure of values. Theoretical advance and empirical tests in 20 countries. Advances in Experimental Social Psychology, Vol. 25, pp. 1-65.

13 Grunert, S. C. and Juhl, H. J. (1995) 'Values, environmental attitudes, and buying of organic foods', Journal of Economic Psychology, Vol. 16, No. 1, pp. 39-62.

14 Grunert, S. C. and Muller, T. E. (1999) 'Measuring values in international settings: Are respondents thinking "real" life or "ideal" life?', in Manrai, L. A. and Manrai, A. K. (eds) 'Global perspectives in cross-cultural and cross-national research', pp. 169-186, The Haworth Press, New York.

15 Grunert, S. C. and Scherhorn, G. (1990) 'Consumer values in West Germany: Underlying dimensions and cross-cultural comparison with North America', Journal of Business Research, Vol. 20, No. 2, pp. 97-107.

16 Kahle, L. R., Beatty, S. E. and Homer, P. (1989) 'Consumer values in Norway and the United States: A comparison', Journal of International Consumer Marketing, Vol. 1, No. 4, pp. 81-92.

17 Riesmann (1950) op. cit.

18 Dahl, H. (1997) 'Hvis din nabo var en bil — en bog om livsstil', Akademisk Forlag.

19 Askegaard, S. (1993). 'Livsstilsundersøgelser — henimod et teoretisk fundament'.

20 Wells, W. D. and Tigert, D. J. (1971) 'Activities, interests and opinions', Journal of Advertising Research, Vol. 11, August, pp. 27-35.

21 Christiansen, C. P. and Hansen, F. (2000) 'The use of social psychological and applied value research for the measurement of cultural differences among consumers', proceedings from the III Asian ACR Conference, Surfers Paradise, Australia, March.

22 Arnaa, C. et al. (1999) 'Profiling media users: An operational instrument for the measurement of cultural values in a wide variety of cultures', proceedings from the Esomar Conference, Mexico City, 1998.

23 Hansen, F. (2002) 'Survey-research: A substitute for single-source data', Admap, London, January.

24 Arnaa et al. (1999) op. cit.

25 SPSS $^{\circledR}$ Base 7.0 for Windows ${ }^{(\boxplus M)}$ User's Guide (1996). 